\begin{abstract}
Марія Бовсуновська,
аспірантка Інституту української мови НАН України. mariabovsynovska@gmail.com
\end{abstract}

\title{
МОВНА АСИМІЛЯЦІЇ ПОЛЯКІВ НА ЖИТОМИРЩИНІ
}

У статті описано історико-культурні умови заселення поляками території сучасної Житомирщини. 3'ясовано, щзо поляки, одна з найбільших нацменшин, яка зазнала асиміляиії під впливом украӥнської культури. Національна й мовна самоідентифікація поляків почала втрачатися з першої чверті ХХ ст. За матеріалами перепису 2001 року зростає вибір польської мови як рідної. На території Житомирської області мовна асимілящія поляків $\epsilon$ вищою, ніж в Украйні загалом. Польська етноменшина, хоч і не в повній мірі, проте має змогу задовольняти свої культурно-інформаційні потреби (споживання ЗМІ, читання книжск), оскільки на Житомирщині є польськомовні теле- та радіопередачі, друковані видання та ін.

Ключові слова: мовна ситуачія, мовна асимілячія, рідна мова, національна й мовна самоідентифікаиія.

\section{Bowsunowska Maria. Asymilacja językowa Polaków na Żytomierszczyźnie}

W artykule przeanalizowano kulturowo-historyczne warunki osadnictwa przez Polaków terytorium współczesnej Żytomierszczyzny. Wyjaśniono, że Polacy będąc jedna z największych mniejszości narodowych, zaznali asymilacji pod wptywem kultury ukrainskiej. Tożsamość narodowa i językowa Polaków zaczęła tracić się w pierwszej ćwierci XX wieku. Na podstawie materiałów spisu 2001 roku zacząt rosnać wybór języka polskiego jak ojczystego. Na terytorium obwodu żytomierskiego asymilacja językowa Polaków jest wyższa, niż na Ukrainie w ogóle. Polska mniejszość narodowa ma możliwość zadowalać swoje potrzeby kulturowo-informacyjne (konsumpcja mediów, czytania

książek), ponieważ na Żytomierszczyźnie jest polskojęzyczna telewizja oraz audycje radiowe, drukowane czasopisma i in.

Wyrazy kluczowe: sytuacja językowa, asymilacja językowa, język ojczysty, tożsamość narodowa $i$ językowa.

\section{Bovsunovska Maria. The language of assimilation of the Poles in Zhytomyr region}

The article describes the historical and cultural conditions for the settlement of the territory of modern Zhytomyr region by the Poles. It is revealed that the Poles are one of the first national minorities who populated this territory. The Poles moved to Volyn, which included a significant part of modern Zhytomyr region, by several waves (in the 16th-17th centuries, the beginning of the

19th century). The Polish language actively functioned as one of the written languages on Ukrainian lands in the 16th-17th centuries, and until the end of the 18th century on the territory of the former Volyn. With the advent of tsarist Russia, the restrictions of the Polish national minority began, including the language: they could not open Polish-language schools, and teach Polish in educational institutions. Despite these circumstances, the Polish language functioned, and the literature works were written.

The Polish people, most of all national minorities, have been assimilated into the Ukrainian language and the people. The national and linguistic self-identification of the Poles began declining from the first quarter of the 20th century, when the Poles began being restricted themselves to social and political rights. The decline of linguistic and national self-identification has been going

on since the 1970s. The 2001 census indicates the opposite: the choice of Polish as a native language has increased. On the territory of Zhytomyr region, the linguistic assimilation of the Poles is higher than in Ukraine in general. The Polish ethnic minority, though not fully, can satisfy its 
cultural and informational needs (television, radio production, media, reading books), since there are Polish-language television and radio broadcasts and print editions in Zhytomyr.

Key words: language situation, language assimilation, mother tongue, national and linguistic selfidentification.

Постановка проблеми. Територія сучасної Житомирщини 3 давніх часів була поліетнічною. Окрім того, що в краї проживало багато нацменшин (поляки, євреї, росіяни, німці, чехи), вони ще й були численно представлені: інколи на деяких територіях інші національності (євреї, поляки) могли переважати навіть українців. Мовна взаємодія етноменшин між собою й $з$ титульною нацією на території Житомирської області досі належно не вивчена.

Аналіз останніх досліджень і публікацій. Життя поляків на українських землях, зокрема правобережних та Житомирщини, висвітлено в наукових студіях у різних аспектах соціально-економічному (О. Погуляєв [11]), історіографічному (О. Білобровець [3], О. Буравський [4], Н. Рудницька [15]), культурно-освітньому (М. Левківський, Л. Антонюк [1]), літературному (В. Сршов [6]). В інформаційно-довідковому виданні «Польські поселення Житомирщини» описано історію поширення польської національної меншини на території Житомирської області, зокрема в книзі наявні історичні та статистичні відомості про ті населені пункти, де згідно з переписом 1989 р., проживало польське населення [13]. Мовна ситуація в староукраїнський період на цих землях була предметом опису В. Мойсієнка [10], В. Титаренко [16] та інших дослідників. Уподібнення нацменшин в мовному плані розглядалося в працях Л. Воцюр (євреї у Львові) [5], Ю. Жлуктенка [7]. Мовна асиміляція поляків на Житомирщині дотепер залишалася поза увагою мовознавців. Тому мета цієї статті - простежити, як відбувалося мовне уподібнення польської національної меншини на території сучасної Житомирщини.

Виклад основного змісту. Поляки почали масово з'являтися на території Волині найраніше 3 усіх етнічних меншин, вони переселялися 3 етнічної Польщі в кінці XIVXVIII ст. Перехід волинських земель під протекцію речі Посполитої спричинив досить потужну хвилю колонізації польської людності, особливо це відбувалося в XVI ст. За соціальним складом переселялись переважно польські магнати й безземельна шляхта, яка отримувала тут земельні наділи, та селяни-втікачі.

Друга масова хвиля поляків була на Волині на початку XIX ст. Потужний наплив поляків підтримувався царськими указами $(1804,1817$ рр.) з метою економічного розвитку губернії. Міграція поляків активно відбувалася й у середині XIX ст., зокрема на початку 60-х pp. і у 80-90-х рр. Оселялися поляки переважно в сільській місцевості. 3 часом російський уряд, усвідомивши величезну кількість переселенців з Польщі, почав видавати циркуляри, які б перешкоджали іноземному заселенню краю. О. Буравський наводить зміст двох циркулярів, у першому 3 яких (1893р.) містилось розпорядження про заборону іноземним вихідцям (переважно полякам) проживати за міськими поселеннями, а також на майбутнє набувати нерухоме майно на праві власності або оренди, за винятком переселенців, які сповідували православну віру. У другому було завдання місцевим чиновникам зібрати інформацію про вихідців польського походження з Привіслянського краю, які проживали в містах, містечках i селах $[4$, c. 27]. Попри ці та інші укази (розпорядження) чисельність польського населення на початку XX ст. на Волині продовжувала зростати [4, с. 29].

Дані Першого загального перепису населення Російської імперії 1897 р. засвідчують, що у Волинській губернії мешкав 184161 поляк (6,2%). У повітах, територія яких потім увійшла до Житомирської області, відсоток поляків був меншим від середнього порівняно, наприклад, з Луцьким, Рівненським, Володимир-Волинським повітами, а саме: у НовоградВолинському повіті поляків було 5,22 \% від повітового населення, у Житомирському повіті 5,68 \%, найменше в Овруцькому. Попри те, що загалом у колишніх губерніях Житомирщини проживало менше поляків, ніж, наприклад, на заході Волинського краю, у самому Житомирі 
їх була найвища концентрації - 7464 особи (11,33 \% від усього населення міста), у НовоградВолинському 1291 особа (7,63 \%), дещо менше в Овручі - 152 особи (2,06 \%) [4, с. 29].

Російський уряд уживав заходів до послаблення можливостей польських урядовців і польських поміщиків чинити вплив на міське населення, і це супроводжувалося, зокрема, витісненням поляків з адміністрації й узагалі з міст. Відповідно зростала й кількість поляків, які безпосередньо займалися землеробством і працювали в переробних галузях. На початку $\mathrm{XX}$ ст. 48,6 \% поляків Правобережжя займалися рільництвом, понад 24 \% працювали в промисловості, 2,2 \% - у торгівлі, майже $16 \%$ становили лікарі, учителі, адвокати та $11 \%$ чиновники, духовенство, домашня прислуга [17, с. 255-256].

3 другої половини XIX ст. російський уряд уживав можливі заходи для впровадження російської мови в усі царини та витісненя української й мов нацменшин. Зокрема міністерство народної освіти в 1868 році ініціювало височайший указ згідно з яким мали вивчати російську мову в усіх школах національних меншин 3 виховною метою асимілятивною [1, с. 61]. Активними були дії тодішнього уряду й щодо шкіл, зокрема й етноменшин: «припускаючи існування школи з польською і німецькою мовами викладання 3 міркувань іншого порядку, а не з визнання доцільності викладання рідною мовою загалом, творці Статуту 1804 р. не встановили викладання рідною мовою ... для інших груп населення ... Польське повстання 1830 і 1831 року викликало ще більші обмеження польської школи» [цит. за: 1, с.160]. А 4 квітня 1831 року вийшло височайше повеління, щоб «докласти більших зусиль до якнайшвидшого виконання наявних приписів щодо поступового знищення духовних училищ при римо-католицьких монастирях $\mathrm{i}$ про викладання російською мовою в світських училищах, що їх замінять, маючи постійну мету спрямування публічного виховання до зближення тамошніх мешканців 3 природними росіянами» [цит. за: 1, с.160].

Польська громада на Волині була не лише однією з найбільших за чисельністю серед етнічних меншин, а й найбільш потужною в суспільно-політичному й культурному житті українців, оскільки переважно поляки складали соціальну еліту правобережних губерній Російської імперії.

Поляки на Волині в XIX ст., попри політичні утиски й мовно-культурні обмеження, масово творили літературу польською мовою (А. Фелінський, Г. Ржевуський, Ю. Крашевський, Т. Бобровський, С. Фелінська, Н. і Г. Олізари, М. Чайковський та інші), а відповідно активно впливали на соціокультурне тло краю. Цей вплив досить грунтовно висвітлений у монографії В. Єршова, який розглядає польськомовну літературу Волині «як таксономічну частку власне польської літератури Правобережжя, органічну таксономічну частку польськомовної літератури Правобережжя і водночас як органічну таксономічну складову української літератури» [6, с. 9]. За словами дослідника ця література «стала унікальним феноменом і високим зразком регіонального існування і функціонування в складних, навіть більше, надскладних умовах» [там само, с. 14].

Дослідники (К. Грімстед, В. Мойсієнко, В. Титаренко, І. Чепіга, Н. Яковенко) зауважують, польська мова майже послідовно витісняла українську з правничої царини: починаючи 3 другої половини XVII ст. документації з Польської резиденції видається королями лише польською мовою, на Правобережжі частина актових книг (наприклад, овруцькі) велася польською мовою тощо. Спочатку на законодавчому рівні руська (староукраїнська) мова визнавалася офіційно й уживання ії документально не заперечувалося, але з 1669 року була видана постанова про те, що польський король буде видавати документи польською та латинською мовою [16, с. 157-158]. Якщо в державно-правовій царині з другої половини XVII ст. насамперед на Правобережжі польська мова впроваджувалася насильно, то, за словами В. Титаренко, «у мистецькому житті вибір мови для автора був добровільним» [16, c. 157], тому частина авторів писала двома мовами або перекладали на польску. В царині освіти й життя української шляхти панувала польська культура. Як стверджує В. Сршов, «польська мова, починаючи зі століття XVI і до першої половини XIX ст. на теренах 
Правобережної України, Литви й Білорусі є однією з мов літератури й культури взагалі для українців, а також литвинів і білорусів» [6, с. 17]. Отже, на Правобережжі поляки й польська мова панували аж до XIX ст., обмежуючи українську культуру та мову в ужитку в різних царинах, зокрема в діловодстві, почасти в художній літературі.

За даними перепису населення СРСР 1926 року у Волинській окрузі мешкало 690119 осіб, серед яких: українців - 66,8 \%, поляків - 12,6\%, євреїв - 9,5\%, німців - 7,3\%, росіян $2,9 \%$. Питома вага національних меншин у структурі населення Житомирщини становила понад 30 \%. У цей період політика держави була спрямована на підтримку мов національних меншин. I. Міронова зазначає, що «...проведення виборчих кампаній мовами національних меншин уперше широко здійснювалося в 1925-26 pp., хоч така робота проводилася й раніше. Представники національних меншин уводилися до складу виборчих комісій; звіти окружних і районних виконкомів робилися, як правило, відповідною мовою; документація й виборча література також видавалася мовами багатьох національностей» [9, с. 42]. У 1926-27 навчальних роках у Житомирі працювала польська радпартшкола. У цей період під час створення національно-територіальних одиниць в Україні на Житомирщині був створений єдиний польський національний район - Мархлевський (центр місто Довбиш) [там само, с. 41], який існував у 1925-35 роках. Проте вже в 30-х роках багато польських сімей зазнали репресій та були виселені 3 цього краю у зв'язку 3 тодішніми суспільно-політичними подіями. Наприклад, у 1930-му році 608 родин (27,7 \% усіх селянських родин) були репресовані з Коростенської й Волинської округи [14, с. 18-19]. 3 цього часу поляків на території Житомирщини, як і загалом України, за переписами стає значно менше, що можемо пояснювати різними причинами: репресіями, війною, переселенням, а також асиміляцією до українців, адже значна частина польської людності могла свідомо вказувати в графі національність «українець». Зменшення кількості поляків відчутним є аж до 2001 року, відтоді національні переписи не проводилися. Зважаючи на теперішні польсько-українські відносини кількість поляків за національністю в Україні, напевно, зросте за рахунок тих, хто захоче відновити свою етнічну належність.

Достовірну динаміку асиміляції поляків на Житомирщині можна простежити з 1959 року, оскільки з того часу маємо точні дані на незмінюваній території.

За переписом 1959 року в Житомирській області проживало 102995 поляків, що становило 6,4 \% від усього населення краю. Із них 7,6 \% обрали рідною мовою польську, $88,8 \%$ - українську, 3,4 \% - російську, $0,13 \%$ - іншу.

Кількість поляків до 1970 року зменшилась на 12275 осіб, і за переписом цього року налічувалось 90720 осіб (5,6 \%). Із них 1,8 \% обрали рідною мовою польську, 93,3 \% українську, $5 \%$ - російську, $0,05 \%$ - іншу. Збільшився вибір української й російської мови, польської та іншої, навпаки, зменшився.

За даними перепису 1970 року більше поляків проживало в сільській місцевості. Аналіз вибору рідної мови продемонстрував, що польське сільське населення зазнало більшої асиміляції до української мови: 3 міської польської етноменшини 2,8 \% обрали рідною мовою польську, 86,3 \% - українську, 10,9\% - російську, 0,08\% - іншу. 3 сільської відповідно $1,0 \%$ польську, 98,5 \% українську, $0,4 \%$ російську, $0,03 \%$ іншу. 3 вищеописаного випливає, що сільська польська етноменшина майже повністю асимілювалася, а в місті на 1,8 \% більше поляків мали мовну самоідентифікацію, яка відповідала національній, та на 10,5 \% більше русифікувалися.

За переписом 2001 року порівняно з 1970 серед польської людності на Житомирщині зріс вибір української мови як рідної на $1,3 \%$, менше обирали російську на $0,8 \%$. Зіставляючи показники Житомирської області із загальноукраїнськими, спостерігаємо суттєву відмінність: загалом в Україні в поляків вищий на 11,9 \% вибір польської мови як рідної $(12,9 \%)$ і більший на $11,4 \%$ вибір російської $(15,6 \%)$, відповідно менший на 23,5\% української (71,0 \%) (див. табл.). 
Вибір рідної мови поляками в Житомирській області за результатами переписів 1959, 1970, 2001 років.

\begin{tabular}{|l|l|l|l|}
\hline \multirow{2}{*}{$\begin{array}{l}\text { Рідна мова } \\
\text { поляків }\end{array}$} & \multicolumn{3}{|c|}{ Рік перепису } \\
\cline { 2 - 4 } Польська & 1959 & 1970 & 2001 \\
\hline Українська & $8,6 \%$ & $1,8 \%$ & $1,3 \%$ \\
\hline Російська & $3,4 \%$ & $93,2 \%$ & $94,5 \%$ \\
\hline Інша & $0,3 \%$ & $5,0 \%$ & $4,2 \%$ \\
\hline
\end{tabular}

Як зазначає Г. Полєтаєв, «сьогодні польська національна меншина Житомирщини отримала правові і соціальні гарантії забезпечення власних культурних, національних i релігійних потреб. Свою діяльність відновили римокатолицькі релігійні общини, з'явилися недільні польські школи...» [12, с. 154]. На Житомирщині на сучасному етапі немає жодної польськомовної школи, проте є кілька шкіл, у яких польська мова є обов'язковою 31 по 11 клас, також є школи, у яких польську мову вивчають як другу іноземну поряд 3 англійською. В області є низка польськомовних газет - «Mozaika Berdyczowska» («Бердичівська мозаїка»), яка заснована й видається Радою бердичівського відділення Спілки поляків України, щоквартальне громадсько-політичне видання «Glos Polonii» («Голос Полонії»), «Те̨сza Żytomierszczyzny» («Веселка Житомирщини»), котру видає Житомирська обласна Спілка поляків України. Також Житомирська обласна Спілка поляків України створила такі інформаційні проекти: телевізійна програма «Поляки Житомирщини» та культурно-освітня програма «Вивчаємо польську» на телеканалі ТРК Союз-ТВ; радіопрограма польською мовою «Єдність» (на радіохвилях державного радіо) та щотижнева польськомовна радіопередача «Польща ближче» на радіохвилях «Польського радіо» м. Бердичева. Організаторів, мету та завдання періодичних видань поляків поряд з іншими нацменшинами описано в праці Т. Безверхої [2, с. 66].

Висновки та перспективи подальших досліджень. Отже, польска етноменшина на Житомирщині тривалий час була однією 3 найбільших, вона найраніше масово почала заселяти ці землі. Зважаючи на суспільно-політичні події, польська людність до XIX ст. не лише мала підтримку влади в мовно-культурному плані, а й активно впливала на культуру та мову української нації. Починаючи з середини XIX століття, російський уряд, усвідомивши загрозу численного польського населення на Житомирщині, почав впроваджувати свідомі дії, спрямовані на асиміляцію цього народу. Простеживши динаміку вибору рідної мови поляками Житомирської області з 1959 року, спостерігаємо майже повну асиміляцію цієї етноменшини до української мови. За даними перепису 2001 року засвідчуємо зміни: зріс вибір польської мови як рідної. На території Житомирської області мовна асиміляція поляків $\epsilon$ вищою, ніж в Україні загалом. Польська етноменшина, хоч і не в повній мірі, проте має змогу задовольняти свої культурно-інформаційні потреби (споживання теле- та радіопродукції, ЗМІ, читання книжок), оскільки на Житомирщині є польськомовні теле- та радіопередачі, друковані видання, активно впроваджується вивчення польської мови в школах.

\section{Список використаних джерел та літератури}

1. Антонюк Л. М. Виховання дітей національних меншин на Волині (XIX - початок XX ст.): порівняльний аналіз: дис. ... канд. пед. наук: 13.00.01. Житомир, 2015. 214 с.

2. Безверха Т. М. Періодичні видання національних меншин Житомирської області як чинник етноінтеграції громадянського суспільства в Україні. Наукові записки Інституту журналістики. 2016. T. 63. C. 64-67. URL: http://nbuv.gov.ua/UJRN/Nzizh_2016_63_14 (дата звернення 12.09.2019).

3. Білобровець О. М. Суспільно-політичний рух поляків Правобережної України у 1863-1914 рр. : автореф. дис. на здобуття ступеня канд. істор. наук. Київ, 2006. 14 с. 
4. Буравський О. А. Поляки Волині у другій половині XIX - на початку XX ст. Житомир, 2004. 168 с.

5. Воцюр Л. Мультикультурне обличчя міжвоєнного Львова. Євреї у місті. URL: http://www.historians.in.ua/index.php/en/istoriya-i-pamyat-vazhki-pitannya/628-lidiia-votsiurmultykulturne-oblychchia-mizhvoiennoho-lvova-yevrei-u-misti (дата звернення 12.09.2019).

6. Сршов В. Польська література Волині доби романтизму: генологія мемуаристичності. Житомир : Полісся, 2008. 624 с.

7. Жлуктенко Ю. А. Мовні контакти. Проблеми інтерлінгвістики. Київ : Вид-во Київ. ун-ту, 1966. $135 \mathrm{c}$.

8. Малиновский Л. В. Немцы в России и на Алтае: популярно-исторические очерки. Барнаул, 1995. $182 \mathrm{c}$.

9. Міронова І. С. Національні меншини України : навч.-метод. посіб. Миколаїв-Одеса : ТОВ ВіД, 2006. $304 \mathrm{c}$.

10. Мойсієнко В. М. Фонетична система українських поліських говорів у XVI-XVII ст. Житомир : Видво ЖДУ ім. І. Франка, 2006. 446 с.

11. Погуляєв О. Соціально-економічне життя поляків Правобережної України у добу української

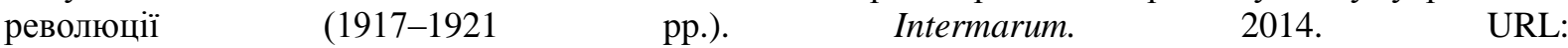
http://eprints.zu.edu.ua/16325/1/\%D0\%9F\%D0\%BE\%D0\%B3\%D1\%83\%D0\%BB\%D1\%8F\%D1\%94\%D0 \%B2.pdf (дата звернення 12.09.2019).

12. Полєтаєв Г. Польські поселення на Житомирщині. Польські студї̈ «Дух $і$ літера». № 22. URL: http://ekmair.ukma.edu.ua/handle/123456789/4776 (дата звернення 12.09.2019).

13. Польські поселення Житомирщини : довід.- інформ. вид. / ред.-упоряд. Ю. С. Кондратюк. Житомир : Видавництво ПП Євенок О. О., 2011.232 с.

14. Реабілітовані історією: У двадцяти семи томах. Житомирська область. У семи книгах. Книга перша, 2006.

15. Рудницька Н. Репатріація польського населення Житомирської області до Польщі у 1944-1946 рр. Intermarum: історія, політика, культура. 2016. Вип. 3. С. 246-257.

16. Титаренко В. Мовна ситуація на північноукраїнських землях у XVI-XVII ст. Украӥнська полоністика. Житомир: Видавництво Житомирського державного університету імені Івана Франка, 2008. Вип. 5. С. 153-164.

17. Jabłoński H. Polska autonomia narodowa na Ukrainie 1917-1918. Pisma wybrane. Z rozważań o II Rzeczypospolitej. Wroclaw, 1987.

\section{References (translated \& transliterated)}

1. Antoniuk, L. M. (2015). Vykhovannia ditei natsionalnykh menshyn na Volyni (XIX - pochatok XX st.): porivnialnyi analiz [Parenting of children of national minorities in Volyn (XIX - beginning of XX century): a comparative analysis]. Candidate's thesis. Zhytomyr [in Ukrainian].

2. Bezverkha, T. M. (2016). Periodychni vydannia natsionalnykh menshyn Zhytomyrskoi oblasti yak chynnyk etnointehratsii hromadianskoho suspilstva $\mathrm{v}$ Ukraini [Periodicals of national minorities of Zhytomyr region as a factor of ethnointegration of civil society in Ukraine]. Naukovi zapysky Instytutu zhurnalistyky Scientific notes of the Institute of Journalism, 63, 64-67. Retrieved from http://nbuv.gov.ua/UJRN/Nzizh_2016_63_14 [in Ukrainian].

3. Bilobrovets, O. M. (2006). Suspilno-politychnyi rukh poliakiv Pravoberezhnoi Ukrainy u 1863-1914 rr. [Socio-political movement of the Poles of Right-Bank Ukraine in 1863-1914]. Extended abstract of candidate's thesis. Kyiv [in Ukrainian].

4. Buravskyi, O. A. (2004). Poliaky Volyni u druhii polovyni XIX - na pochatku XX st. [Poles of Volhynia in the second half of XIX - beginning of XX century]. Zhytomyr [in Ukrainian].

5. Votsiur, L. (2013). Multykulturne oblychchia mizhvoiennoho Lvova. Yevrei u misti [Multicultural face of the interwar Lviv. Jews in the city]. (n.d.) Retrieved from http://www.historians.in.ua/index.php/en/istoriyai-pamyat-vazhki-pitannya/628-lidiia-votsiur-multykulturne-oblychchia-mizhvoiennoho-lvova-yevrei-umisti [in Ukrainian].

6. Yershov, V. (2008). Polska literatura Volyni doby romantyzmu: henolohiia memuarystychnosti [Polish Literature of Volyn Period of Romanticism: The Genology of Memoirism]. Zhytomyr: Polissia [in Ukrainian].

7. Zhluktenko, Yu. A. (1966). Movni kontakty. Problemy interlinhvistyky [Language contacts. Problems of interlinguistics]. Kyiv: Vyd-vo Kyiv. un-tu [in Ukrainian].

8. Malinovskiy, L. V. (1995). Nemtsy v Rossii $i$ na Altaye: populyarno-istoricheskiye ocherki [National minorities of Ukraine. Teaching manual]. Barnaul [in Russian]. 
9. Mironova, I. S. (2006). Natsionalni menshyny Ukrainy [National minorities of Ukraine]. Mykolaiv-Odesa: TOV ViD [in Ukrainian].

10. Moisiienko, V. M. (2006). Fonetychna systema ukrainskykh poliskykh hovoriv u XVI-XVII st. [The phonetic system of Ukrainian Polissya speeches in the XVI-XVII centuries]. Zhytomyr: Vyd-vo ZhDU im. I. Franka [in Ukrainian].

11. Pohuliaiev, O. (2014). Sotsialno-ekonomichne zhyttia poliakiv Pravoberezhnoi Ukrainy u dobu ukrainskoi revoliutsii (1917-1921 rr.) [Socio-Economic Life of Poles of Right-Bank Ukraine in the Age of the Ukrainian Revolution (1917-1921)]. Intermarum. Retrieved from http://eprints.zu.edu.ua/16325/1/\%D0\%9F\%D0\%BE\%D0\%B3\%D1\%83\%D0\%BB\%D1\%8F\%D1\%94\%D0 \%B2.pdf [in Ukrainian].

12. Polietaiev, H. (2010). Polski poselennia na Zhytomyrshchyni [Polish settlements in the Zhytomyr region]. Polski studii «Dukh $i$ litera» - Polish studios «Spirit and Letter», 22. Retrieved from http://ekmair.ukma.edu.ua/handle/123456789/4776 [in Ukrainian].

13. Kondratiuk, Yu. S. (Eds.). (2011). Polski poselennia Zhytomyrshchyny [Polish settlements of Zhytomyr region]. Zhytomyr: Vydavnytstvo PP Yevenok O. O. [in Ukrainian].

14. Reabilitovani istoriieiu: $U$ dvadtsiaty semy tomakh. Zhytomyrska oblast. (2006). [Rehabilitated by History: Twenty-seven volumes. Zhytomyr region]. U semy knyhakh. Knyha persha [in Ukrainian].

15. Rudnytska, N. (2016). Repatriatsiia polskoho naselennia Zhytomyrskoi oblasti do Polshchi u 1944-1946 rr. [Repatriation of the Polish population of the Zhytomyr region to Poland in 1944-1946]. Intermarum: istoriia, polityka, kultura, issue 3. 246-257. [in Ukrainian].

16. Tytarenko, V. (2008). Movna sytuatsiia na pivnichnoukrainskykh zemliakh u XVI-XVII st. [The Language Situation on the North Ukrainian Lands in the 16th - 17th Centuries]. Ukrainska polonistyka - Ukrainian Polonistics. Zhytomyr: Vydavnytstvo Zhytomyrskoho derzhavnoho universytetu imeni Ivana Franka, issue 5. 153-164 [in Ukrainian].

17. Jablonski, H. (1987). Polska autonomia narodowa na Ukrainie 1917-1918. [Polska autonomia narodowa na Ukrainie 1917-1918]. Pisma wybrane. Z rozwazan o II Rzeczypospolitej. Wroclaw [in Poland]. 